\title{
Protection OF REPUTED TRADEMARKS AND KEYWORDS: LOOKING FOR ARIADNE'S THREAD AMONG Flowers, Perfumes AND BAgS
}

Elisa Moro*

\begin{abstract}
Historically, in the majority of judicial systems, the protection of trademarks with reputation differs from the protection of normal trademarks. It is widely recognised that reputed trademarks have an "added value" deserving wider protection. The contribution analyses the evolution of the protection of trademarks with reputation in the European Union legislation and the jurisprudence of the Court of Justice of the European Union (CJEU). The First Directive strengthened the protection of trademarks with reputation both in the field of registration and in the field of infringement. Article 5(2) of the TMD leaves to Member States the possibility to protect well-known trademarks against dilution. Third parties can be prevented by the proprietor of the trademark with reputation from using signs identical or similar to this trademark. The use must take place in the course of trade, the products or services with which it is related should be similar to those for which the trademark is registered and it must take unfair advantage of the distinctiveness of the trademark or be detrimental to it. Considering the internet features, its availability worldwide and the growing number of users, it is evident that is essential for a trademark to expand its reputation and monitor if it is used by third parties that can damage its reputation or take advance of it. The protection of reputed trademarks on the internet is very discussed and problematic. Many actions have been brought for trademark infringement by the use of similar or identical signs ad keywords in search engines. The ECJ tried to order and clarify the application of EU legislation to these particular cases (Vuitton v Google, L'Oreal v Ebay and Interflora v Marks and Spencer).
\end{abstract}

\section{A. INTRODUCTION}

Trademarks are crucial in companies' marketing strategies: their essential function, the function of origin, allows undertakings to distinguish and individualize their products or services from that of their competitors. They can promote their name and strengthen their image and reputation in consumers' eyes.

The aim of trademark protection is plural: the trademark owner's interest for the identification, the interest of the consumer of having a real freedom of choice and a public interest of establishing and maintaining

\footnotetext{
* Ph.D. candidate at 'Scuola Dottorale Internazionale di Diritto ed Economia "Tullio Ascarelli'” -Diritto privato per l'Europa- Roma Tre University.
} 
competition based on quality. ${ }^{1}$ The balancing of these different interests draws the limits of trademark protection: an absolute protection would lead to the creation of a monopoly for the trademark's owner that would be incompatible with the above-mentioned interests and thus create a prejudice for competitors. ${ }^{2}$

Traditionally, the protection of trademarks has been centred on the essential function of origin. However, the evolution of the market, of the meaning of trademarks, as well as the identification of different functions, has highlighted the need for a different kind of protection against new kinds of aggressions, especially for reputed trademarks. ${ }^{3}$

Products and services are always more similar and it is very difficult to improve customer retention. Only strong trademarks distinguish themselves from their competitors. ${ }^{4}$ In the Internet era, taking into account the volume of electronic commerce, there is a need for specific protection of the use of well-known trademarks on websites and internet service providers.

The aim of this paper is to discuss, through an analysis of the case law of the Court of Justice of the European Union (hereinafter: CJEU) and of the General Court, the protection provided by European Union law (hereinafter: EU law) of trademarks with reputation, namely the use of keywords identical or similar to a registered well-known trademark in search engines.

\section{B. REPUTED TRADEMARKS AND EU LAW}

\footnotetext{
${ }^{1}$ Tullio Ascarelli, 'Teoria della concorrenza e interesse del consumatore' (1954) Riv trim dir proc civ, 869.

2 Adriano Vanzetti, 'Equilibrio di interessi e diritto al marchio' (1960) I Rivista di diritto commerciale 261.

${ }^{3}$ Trevor Cook, EU Intellectual property Law (OUP 2010) 254. The use of the words 'trademark with reputation', 'reputed trademark' and 'well-known trademark' will be interchangeable as it is in the jurisprudence of the CJEU, even if in some national system these terms have slightly different meanings.

${ }^{4}$ Celestino Ciocca, Total Brand Experience (Franco Angeli 2004). The strength of a trademark is the power of his reputation to attract customers and convey to the consumer a series of elements that creates in his mind an association to positive values and feelings. Today what the consumer expects when he is choosing to buy a branded product or service is not anymore the mere correspondence with a quality standard but a total experience of the feelings that he associates with the trademarks' 'aura'.
} 
Trademark law in Europe has been the subject of several legislative initiatives. Directive $89 / 104 / \mathrm{EEC}^{5}$ (the first TMD) and Directive 2008/95/EC ${ }^{6}$ (hereinafter: TMD), that replaced the first without substantial modifications, have harmonised the substantive laws of Member States. Regulation (EC) No 40/95 (first CTMR) created the Community trademark and the Regulation (EC) No $207 / 2009^{8}$ (hereinafter: CTMR) pursued the establishment of a unitary system of protection.

The CJEU has received numerous referrals pertaining to the interpretation of the directives and regulations, most of them regarding the notion of "use in the course of trade" and the notion of "function of the trademark" .

For the purpose of this discussion, it is important to note that the CJEU, after initially only focussing its attention on the function of origin as the essential function, began to consider other functions of trademarks, especially in relation to trademarks with reputation. The recent jurisprudence of the Court is full of references to "other functions": the importance of advertising, goodwill, communication and investment functions taken into serious account when assessing the damage to a trademark's reputation. The advertising function represents the investments made by the trademark owner to develop the image of his mark. This function is linked to the communication function that is the "evocative power of the trademark to convey characteristics, images, and feelings to the public" $"$. The goodwill function is the "image" of the trademark represented by these characteristics, images and feelings. ${ }^{11}$ The CJEU has explicitly recognised all the

\footnotetext{
${ }^{5}$ Directive 89/104/EEC of 21 December 1988 to approximate the laws of Member States relating to trademarks, [1989] OJ L40/1.

${ }^{6}$ Directive 2008/95/EC of 22 October 2008 to approximate the laws of Member States relating to trademarks (codified version) [2008] OJ L299/25.

${ }^{7}$ Council Regulation (EC) No 40/94 of 20 December 1993 on the Community trademark [1994] OJ L 11/1.

${ }^{8}$ Council Regulation (EC) No 207/2009 of 26 February 2009 on the Community trademark (codified version) [2009] OJ L78/1.

${ }^{9}$ See for a general description of the attitude of the CJEU in the interpretation of the Directive 89/104/EEC, WR Cornish and David Llewelyn, Intellectual Property: Patents, Copyright, Trade Marks and Allied Rights (6th edn, Sweet \& Maxwell 2007).

${ }^{10}$ Ciocca (n 4).

${ }^{11}$ T.Cohen Jehoram, CJJC.Van Nispen, JLRA Huydecoper, European Trademark Law (KLI 2010) This image can be related to luxury, exclusivity, lifestyle and even the attitude of the consumers to the trademark, for instance the fact that products or services bearing a particular trademark are popular in a highly regarded group of the population.
} 
abovementioned different functions in the L'Oreal v Bellure ${ }^{12}$ case, a case considered to be a turning point in the development of the case law on the protection of trademarks.

\section{The Protection of Trademarks with Reputation}

Trademarks with reputation benefit first from the same protection granted to trademarks in general against the risk of confusion. In addition, they are protected against dilution, meaning the loss of the capacity to have a singular association in the public mind with a particular product.

According to Article 5(1) of the TMD, the owner of a registered trademark should have an exclusive right to use the trademark in the course of trade, i.e. he should be able to prevent third parties from using it in the course of trade:

"(a) any sign which is identical with the trademark in relation to goods or services which are identical with those for which the trademark is registered" and

"(b) any sign where, because of its identity with, or similarity to, the trademark and the identity or similarity of the goods or services covered by the trademark and the sign, there exists a likelihood of confusion on the part of the public; the likelihood of confusion includes the likelihood of association between the sign and the trademark."

If for trademarks in general, enabling the owner of a trademark to prevent the use of a sign similar or identical to the registered trademark for similar or identical products or services by third parties seems sufficient to ensure the identification of the source of the products and the services for which the trademark is registered ${ }^{13}$, the same is not true to grant an adequate protection to well-known trademarks.

Article 5(2) of the TMD, implemented by all Member States of the $\mathrm{EU}^{14}$, provides the possibility to protect well-known trademarks against dilution. The proprietor of a trademark that has a distinctive character shall be entitled to prevent third parties from using in the course of trade "any sign which is identical with, or similar to, the trade mark in relation to goods or

${ }^{12}$ Case C-487/07, L'Oreal and others v Bellure and others [2009] ECR I- 05185.

${ }^{13}$ Case C-102/77, Hoffman Roche v Centrafarm, [1978] ECR I-01139.

${ }^{14}$ Cook (n 3). 
services which are not similar to those for which the trade mark is registered" if the use of that sign "without due cause takes unfair advantage of, or is detrimental to, the distinctive character or the repute of the trade mark".

\section{(a) Reputation}

According to settled case law of the $\mathrm{CJEU}^{15}$, a trademark should have a certain "degree of knowledge" in order to benefit from the wider protection of Article 5(2). The trademark must be "known by a significant part of the public concerned by the goods or services" for which the trademark is registered ${ }^{16}$. The Court gives a flexible definition of "significant" taking into account the sector of the activity of the trademark, without referring to a particular percentage ${ }^{17}$. It is not necessary that the territorial extension of the reputation involves a whole Member State, it is sufficient for the trademark to have a reputation in "a substantial part"18 of a Member State. The General Court reached an interesting conclusion in recognising the reputation of a sign due to its "importance to the world's economy in general, and the media" ${ }^{19}$. The trademark had continued and there was widespread visibility on many reviews and newspapers, it was "very commonly mentioned on radio and television in the European Union, both in financial broadcasts and in general news programme" ${ }^{20}$ even if there was no proof of the use of the trademark to promote services for whom it was registered.

The CJEU is quite restrictive about the burden of proof required for a trademark to demonstrate its reputation. It is for the parties to allege all the relevant facts for the evaluation ${ }^{21}$. The General Court seems less restrictive: the reputation does not need to be proved if there is a commonly held public view that the trademark is well known, moreover if one of the parties does not contest it ${ }^{22}$. The Court repeated on several occasions that the

\footnotetext{
${ }^{15}$ Case C-375/97 General Motors Corp v Yplon SA [1999] E.C.R. I-5421, para 28.

${ }^{16}$ CaseT-8/03, El Corte Ingles $v$ Office for Harmonisation in the Internal Market [2004] ECR II-04297, para 67.

${ }_{17}^{17}$ General Motors (n 15), paras 24-25.

${ }^{18}$ ibid para 28.

${ }^{19}$ Case T-47/06, Antartica Srl v Office of Harmonization in the Internal Market [2007] ECR II-00042 at paragraph 31.

${ }^{20}$ ibid.

${ }^{21}$ General Motors (n 15) para 27.

${ }^{22}$ Case T-67/04 Spa Monopole v Office for Harmonisation in the Internal Market [2005]

E.C.R. II-01825, paras 27-28.
} 
appreciation of the reputation should be global and should be based on the "overall impression" created by the visual, aural or conceptual similarity ${ }^{23}$.

\section{(b) Dilution}

Trademarks with a reputation convey a message that is not only about the origin of the product or service: the consumer perceives them as "an emblem of prestige or a guarantee of quality ${ }^{\prime 24}$. This is the brand image, the distinctive nature of the mark, which can be damaged even when consumers are not confused.

When an undertaking decides to profit from the distinctiveness that a trademark has acquired by using a sign identical or similar to that trademark, without the consent of the trademark's owner, he is taking unfair advantage of the repute of the mark. This use causes problems for the capacity of the trademark to distinguish its products or services for which it is registered. This dilution can have consequences on the behaviour of consumers. ${ }^{25}$ In order for the trademark's proprietor to prevent this kind of use, the advantage taken must be unfair. ${ }^{26}$ In some cases, indeed, the use of a competitor's trademark does not cause unfair advantage, for instance when the use is descriptive or made in comparative advertising.

The Court expanded the applicability of Article 5(2) of the TDM recognising that dilution can occur also when the sign has been used in relation to similar goods or services ${ }^{27}$ even if there is no risk of confusion.

Dilution, as defined by the General Court in Sigla $v$ OHIM ${ }^{28}$, can manifest itself in different forms: "blurring" is the detriment to the

${ }^{23}$ Case C-251/95 Sabel BV v Puma $A G$ [1997] ECR I-06191 and Case C-342/97 Schuhfabrik Meyer v Klijsen Handel BV [1999] ECR I-03819.

${ }^{24}$ Cornish (n 9).

${ }^{25}$ The Italian Court of First Instance of Rome has stated very clearly that: "The dilution of the well-known trademark annuls the effects expected from the investments made by the company which owns the trademark in order to consolidate its competitive position and acquire new market shares, with the obvious consequent prejudice to the same, and guarantees to the infringing company the possibility of taking advantage, in a parasitic manner, of the said investment, in that the infringing company is enabled to participate in the economic competition without bearing the relevant costs and by virtue of its connection with the activity of a better known competitor, thereby taking undue advantage". Case Adidas-Salomon v Gruppo Coin [2006] ETMR 39, Tribunale di Roma.

${ }^{26}$ Guy Tritton, Richard Davis, Michael Edenborough, James Graham, Simon Malynicz, Ashley Roughton, Intellectual Property in Europe (3th edn, Sweet \& Maxwell 2008).

${ }^{27}$ Case C-292/00 Davidoff and others v Gofkid Ltd [2003] ECR I-389, para 26. 
distinctive character of a trademark which attempts the exclusive link between the product or service and the owner of that trademark. "Tarnishment" is the detriment to the repute of a mark, which provokes the association of the trademark with goods or services that have a negative connotation or are incompatible with the image of the mark. ${ }^{29}$

\section{(c) How far should the Protection against Dilution go?}

It is interesting to note that the wider protection granted to well-known trademarks has raised many discussions. The doctrine is divided. Some authors affirm that the protection against dilution can be excessive because it can lead to the creation of an exclusive right similar to exploitation rights granted for patents and copyrights ${ }^{30}$, while the ratio behind these forms of protection is different. Others argue that the protection against dilution is necessary in order to take into account the effort made by the trademark's owner on the creation of a brand image. ${ }^{31}$

This author shares the view that the burden of proof required by the CJEU, i.e. that the owner has to demonstrate the reputation, the unfair advantage and the detrimental effect, is a safeguard against the expansion of the anti-dilution protection that can become inappropriate if awarded to a well-known trademark each time a sign identical or similar calls it in mind. ${ }^{32}$

\section{TRADEMARKS AND THE INTERNET}

Today it is very difficult for the owner of a trademark with a reputation to monitor the use of that trademark. This is especially true if we consider the

\footnotetext{
${ }^{28}$ Case T-215/03 Sigla v Office for Harmonisation in the Internal Market [2007] ECR II00711, paras 37-39.

${ }^{29}$ Tritton (n 25) 340-346.

${ }^{30}$ Martin Senftleben, 'Keyword Advertising in Europe - How the Internet Challenges Recent Expansions of EU Trademark Protection' (2011) 27 Connecticut Journal of International Law. The author presents an overview of the debate concerning the extent of the protection against dilution. The problem, according to the author, is that the owner of a trademark does not create something that furthers science or art, creation that represents the reason of the different protection accorded to copyright and patents, but just makes an investment to improve the market position of an enterprise. Furthermore while patents and copyright fall into public domain after a limited period of time, trademarks does not.

31 Martin Senftleben,'The Trademark Tower of Babel - Dilution Concepts in International, US and EC Trademark Law' (2009) 40 Int'l Rev. Intell. Prop. \& Comp. L. 188.

${ }^{32}$ ibid.
} 
Internet's features: its availability worldwide, the growing number of users and the volume of e-commerce. Different kinds of disputes can originate on the Internet from a trademark infringement, the most important and frequent are genuine disputes and cybersquatting. ${ }^{33}$ Domain names are also central for trademark owners and they give rise to a lot of disputes, as well as metatags and search engine keyword sales. ${ }^{34} \mathrm{We}$ will focus our attention on this last category examining the jurisprudence of the CJEU in an attempt to delineate the parameters of reputed trademark protection for keywords.

\section{The Keywords Sale}

Search engines have developed systems of advertising from which they earn the majority of their profits. ${ }^{35}$ Keyword selling works more or less in the same way for all search engines, but we will take Google's AdWords service as an illustrative example to understand their functioning. Anyone who wants to advertise his/her website can "create ads and choose keywords, which are words or phrases related to their business" ${ }^{36}$. When the owner of a website chooses some keywords, the link will appear in the page of search results corresponding to the keywords when the internet user types these

\footnotetext{
${ }^{33}$ GJH.Smith, Bird\&Bird, Internet Law and Regulation (4 ${ }^{\text {th }}$ edn, Sweet \& Maxwell 2007) 144. Genuine disputes regard the circumstance of both parties having a legitimate claim. They arise when the same trademark is owned and used by different persons in respect of different goods or services and when the same occurs but the trademark is used in different countries in relation to the same goods or services. Cybersquatting is a practice of registering domain names before the trademarks owner in order to exact a price from the company for transferring the domain name to the trademark owner.

34 ibid. Domain names are mostly discussed in relation to the modalities of their registration and the way to prevent it in case of abusive behaviour, metatags are words used in a particular section of a website, the text contained in that part is hidden from the normal user of the website but is visible to users of HTML or others source codes. Problems with metatags arise because that are visible also to search engines and influence the searching results. Including a competitor's trademark in the website's keywords can divert business to this website.

${ }^{35}$ Manavinder S.Bains, 'The Search Engine Economy's Achilles Heel? Addressing Online Parallel Imports Resulting from Keyword and Metatag Misuse' (2006) 6 Stan Tech L Rev 78. The author stresses out that the introduction of the AdWords service was fundamental for the growth of search engines revenues. See also J. Batelle, 'Google e gli altri. Come hanno trasformato la nostra cultura e riscritto le regole del business' Milano 2006.

36 'AdWords, how it works', available at

$<$ https://accounts.google.com/ServiceLogin?service=adwords\&cd=GB\&hl=en_GB\&ltmp $\mathrm{l}=\mathrm{jfk} \&$ passive $=$ true $\& \mathrm{ifr}=$ false $\&$ alwf $=$ true $\&$ continue $=\mathrm{https}: / /$ adwords.google.co.uk/um/gai aauth?apt $\% 3$ DNone $\% 261 \mathrm{tmpl} \% 3 \mathrm{Djfk} \&$ sacu= $1 \&$ sarp $=1 \&$ sourceid=awo\&subid $>$ accessed on 14 June 2013.
} 
words into the search engine. These "sponsored links" appear next to the "natural" search results, on the upper part or on the right side of the search engine page. Advertisers pay a price "per click" or a "price per impression" for this service. As there is no limitation in the keywords' selection and several advertisers can choose the same keywords, this price varies according to the place in the list of the sponsored links that the buyer wants.

The purchase of keywords is the choice of the advertiser and almost any word can be chosen ${ }^{37}$. Normally businesses chose their own trademark and terms related to their business. Problems arise when they chose a trademarketed name that is the property of competitors. The use of a third party trademark as a keyword or as a part of the advertising message can lead to an unfair advantage taken from another trademark's goodwill and drawing power ${ }^{38}$. This leads to trademark owners suing advertisers and search engines for infringement. Looking at their pleadings $\mathrm{s}^{39}$ we find claims of distracting or misleading advertising, of consumer confusion, or of unauthorised selling of trademarks.

While advertisers' liability for trademark infringement did not cause many interpretative problems, search engine liability has generated a big debate.

\section{The Hosting Exemption}

The Electronic Commerce Directive ${ }^{40}$ (hereinafter: ECD) contains a general principle of exemption from criminal and civil liability for service providers, Articles 12 to 15 establish three different regimes according to the nature of

\footnotetext{
${ }^{37}$ Ibid. Words and advertising messages must respect Google's policy and national laws. Google, in the AdWords and AdSense trademark policy, includes the prohibition of intellectual property infringement and warns advertisers that they "are responsible for the keywords that they choose to generate advertisements and the text that they choose to use in those advertisements".

$<$ http://support.google.com/adwordspolicy/bin/static.py?hl=enGB\&topic=1346940\&guid $\mathrm{e}=1308252$ \&page $=$ guide.cs $>$ accessed on 14 June 2013.

${ }^{38}$ Rick E Bruner, Leland Harden and Bob Heyman, Web marketing 2.0 (Apogeo srl 2001). The choice of metatags and keywords became one of the most important elements in the strategy of brand image promotion on internet.

${ }^{39}$ See Rachel R. Friedman, 'No Confusion Here: Proposing a New Paradigm for the Litigation of Keyword Advertising Trademark Infringment Cases' (2010) Vanderbilt Journal of Entairtainement and Technology Law 355.

${ }^{40}$ Directive 2000/31/EC of 8 June 2000 on certain legal aspects of information society services, in particular electronic commerce, in the Internal Market ('Directive on electronic commerce') OJ L 178, 1-16.
} 
the relevant intermediaries. "Mere conduit" occurs when the activity of the service provider is limited to "the provision of access of a communication network" or to the "transmission of information provided by a recipient of the service". The service provider benefits from the exemption if it does not take part in originating the transmission, if there is no active selection of the receiver of the transmission and if there is no selection or modification of the information that is transmitted. ${ }^{41}$ When the service provider stores information automatically, intermediately or temporarily, his activity is defined as "caching". The exemption from liability, in this case, is available to the service provider if his activity is neutral in processing the information stored or if, in case he has actual knowledge of the illicit nature of the information, he acts "expeditiously to remove or to disable access to the information it has stored" $"$. The last category regulated by the ECD, which is more interesting for this analysis of the protection of trademark with reputation on the internet ${ }^{43}$, is "hosting". The activity of the service provider must be limited to the "storage of information provided by a recipient". The exemption is available if three conditions are fulfilled: no actual knowledge of the illegal activity or information, no circumstances that makes this illegality apparent and expeditiousness in removing or disabling access to information when there is such knowledge or awareness ${ }^{44}$.

To have a complete picture of this regulation and to better understand the findings of the CJEU relating to service providers' liability, it is important to also take into account Article 15 of the ECD. This article contains a key principle for an Internet service provider's liability: Member States cannot ${ }^{45}$ impose a general "monitoring obligation" of the stored or

\footnotetext{
${ }^{41}$ Directive 2000/31/CE, art 12.

42 ibid, article 13.

${ }^{43}$ The CJEU founded both search engines and providers of online markets to be 'hosting providers'.

${ }^{44}$ Directive 2000/31/CE, art 14.

${ }^{45}$ The Electronic Commerce Directive, however, saves the possibility for Member States to require hosting providers to "apply duties of care, which can reasonably be expected from them and which are specified by national law, in order to detect and prevent certain types of illegal activities". This provision could venerate the hosting exemption because in many national systems, in particular in civil law countries, duties of care, when they are not respected, can imply contractual or extra- contractual liability. See in general Carlo Castronovo, La nuova responsabilità civile (3th edn, Giuffré 2006).
} 
transmitted information or a general obligation "actively to seek facts or circumstances indicating illegal activity" 46 .

\section{The Court of Justice of The European Union ANd Keywords}

The following analysis of three recent cases by the CJEU is instructive in delineating the contours of the Court's approach to the protection of trademarks related to keywords.

\section{The Google case}

The Google v Vuitton ${ }^{47}$ case was a reference for preliminary ruling from the French Cour de Cassation for three joined cases. In all three cases the action for registered trademark infringement was brought against the service provider and not against the advertisers and all of the actions had been successful before the national courts. In two of the cases the links displayed, connected to competitor sites, and in one case there was a connection to sites where counterfeit copies of the claimant's products were offered.

The Cour de Cassation asked the CJEU if Article 5(1) of the Directive 89/104/EC ${ }^{48}$ and Article 9(1)(a) and (b) of Regulation 40/94 ${ }^{49}$ should be interpreted as meaning that the proprietor of a registered trademark is entitled to prevent the use of keywords reproducing or imitating his trademark ${ }^{50}$. These keywords were used to display advertising links to sites offering infringed goods in one case $\mathrm{s}^{51}$ and to sites "offering goods identical or similar to those covered by the trademark registration" 52 in the other two cases. The second question related to the interpretation of Article 5(2) of the Directive $89 / 104^{53}$ and Article 9(1)(c) of Regulation $40 / 94^{54}$ as meaning that the proprietor of a trademark with reputation might oppose that

\footnotetext{
${ }^{46}$ Smith (n 32) 385. The rationale of this provision is on one hand the protection of the fundamental freedom of expression and on the other hand the consideration of the costs in which internet service providers would incur if they would be forced to monitor all the information provided by the recipients of the services offered.

${ }^{47}$ Joined Cases C-236/08, C-237/08 and C-238/08, Google France SARL v Louis Vuitton Malletier SA [2010] ECR I-02417.

${ }^{48}$ Directive 89/104/CE (n 6).

${ }^{49}$ Regulation 40/94 (n 8).

${ }^{50}$ Google (n 46) para 32.

51 ibid.

52 ibid, para 37.

${ }^{53}$ Directive 89/104/CE (n 6).

${ }^{54}$ Regulation 40/94 (n 8).
} 
use. ${ }^{55}$ The third question was about the applicability of Article 14 of Directive $2000 / 31$ to the provider of the paid referencing service. ${ }^{56}$ The fourth question was about the liability of advertisers. The Cour de Cassation asked the CJEU if the request of a keyword, which reproduces or imitates a registered trademark to connect to a site selling goods or services is in itself, an infringement, given that the products or services are identical or similar to those designated by the trademark. ${ }^{57}$

Firstly, the Court recalled that the owner of a registered trademark is entitled to prohibit the use of a sign identical to it if three conditions are fulfilled: firstly, the use is in the course of trade, secondly, the use is in relation to identical or similar goods or services to those for which the trademark is registered and thirdly, the functions of the trademark are or may be affected by that use. ${ }^{58}$

\section{(a) The Advertiser's Liabilty}

The Court has stated that advertisers, in this case, use a keyword in the context of a commercial activity because it has the object of displaying a link to the site on which they sell their goods or services ${ }^{59}$. The first condition required is that the use in the course of trade is fulfilled. The second condition required is that the use "in relation to goods or services which are identical with, or similar to, those for which the trademark is registered". Thus, even if the sign used for advertising purposes is not contained in the ad itself, the fact that the keyword selected is identical with a trademark means that the competitor of the trademark proprietor intends to offer an alternative to the goods or services of that proprietor. ${ }^{60}$ The same reasoning applies for a situation in which the advertiser wants to mislead internet users making them believe that the goods or services originate from the trademark's owner or at least that there is an economic connection with such owner. ${ }^{61}$

\footnotetext{
${ }^{55}$ Google (n 46) para 32.

${ }^{56}$ ibidem paras 32- 37.

${ }^{57}$ Ibid, para 41. Some authors considered unusual the inclusion of this question, as no advertiser was party of the case, but it gave to the CJEU the occasion to rule not only on the liability if providers, but also of their customers, the advertisers. See Jonathan Cornthwaite, 'To Key or Not to Key? The Judgment of the European Court of Justice in the Google France AdWords Case' [2010] (7) EIPR 354.

${ }^{58}$ ibid, para 49.

${ }^{59}$ Google (n 46) para 52.

${ }^{60} \mathrm{ibid}$, para 69.

61 ibid, para 72.
} 
In order to verify if the use is liable to have an adverse effect on the functions of a trademark, the Court analyses the function of indicating origin and the function of advertising. It is necessary to take into account the specific manner in which the ad is presented ${ }^{62}$ in order to determine if the function of indicating origin is affected by showing to consumers an ad of a third party on the basis of a keyword identical with a mark. The ad must not suggest that there is an economic link between the trademark owner and the advertiser and must not be vague on the origin of the goods or services rendering it difficult for "a normally informed and reasonably attentive internet user" ${ }^{\prime 63}$ to determine if there is or is not such link. According to the Court:
“(...) the proprietor of a trademark is entitled to prohibit an advertiser from advertising, on the basis of a keyword identical with that trademark which that advertiser has, without the consent of the proprietor, selected in connection with an internet referencing service, goods or services identical with those for which that mark is registered, in the case where that advertisement does not enable an average internet user, or enables that user only with difficulty, to ascertain whether the goods or services referred to therein originate from the proprietor of the trademark or an undertaking economically connected to it or, on the contrary, originate from a third party.,, 64

\section{(b) The Service Providers' Liability}

Regarding the liability of the search-engine operators, the Court has stated that storing and arranging for the display of ads, keywords identical with registered trademarks is a commercial activity, but this does not mean that the service provider itself is using those signs "in the course of trade" ${ }^{25}$. The service provider does not use signs identical or similar to registered trademarks within the meaning of Article 5 of the TMD or of Article 9(1) of the CTM Regulation. The same reasoning applies to reputed trademarks within the meaning of Article 5(2) of the $\mathrm{TDM}^{66}$. Therefore, the storage of

\footnotetext{
62 ibid, para 83.

63 ibid, paras 89-90.

${ }^{64}$ ibid.

${ }^{65}$ Google (n 46) paras 54-57.

66 ibid, para 105.
} 
keywords identical to third parties' trademarks is not liable for trademark infringement even if it occurs in the context of a commercial activity and without the consent of the brand owners. However, the liability of the referencing service provider for other kinds of torts within the meaning of Article 14 of Directive 2000/31 and the availability of the safe-harbour defence should be verified. The Grand Chamber has found that the AdWord service provided by Google is an "information society service" ${ }^{67}$ and analysed whether its conduct was limited to that of an "intermediary service provider" and whether its role was "neutral", the conditions to be fulfilled for the application of the exemption. Note that within the meaning of Article 14 of the Directive 2000/31 the exemption is not available if the service provider was aware that the data or the activities of the recipient were unlawful and did not remove or disable access to the data expeditiously.

The Court has stated that the fact that the service provider "sets the payment terms or provides general information to its clients" 68 cannot deprive it of the exemption. However, the fact that it has a role in the "drafting of the commercial message which accompanies the advertising link or in the establishment or selection of keyword" ${ }^{169}$ may be relevant. It is for national courts to assess if the role of the service provider is "neutral" and if it can profit from the safe-harbour or not ${ }^{70}$.

\section{The L'Oreal v eBay case}

This second case $^{71}$, was a reference from the High Court of England and Wales, in which a dispute arose between L'Oreal on the one hand, being the owner of UK and Community trademarks with reputation; and some individuals selling goods bearing its trademarks and the operator of an online marketplace (eBay), where the products were sold, on the other.

\footnotetext{
${ }^{67}$ ibid, para 110: "the legislature defined the concept of 'information society service' as covering services which are provided at a distance, by means of electronic equipment for the processing and storage of data, at the individual request of a recipient of services, and normally in return for remuneration. Regard being had to the characteristics, summarised in paragraph 23 of this judgment, of the referencing service at issue in the cases in the main proceedings, the conclusion must be that that service features all of the elements of that definition".

${ }^{68}$ Google (n 46) para 116.

69 ibid, para 118.

70 ibid, para 119.

${ }^{71}$ Case C-324/09 L'Oreal and others v eBay International AG and others [2011] not yet published.
} 
L'Oreal claimed that the main problem was that the products being sold by the other individuals were counterfeit or tester and not intended for the market of the European Economic Area. L'Oreal also alleged that eBay was jointly liable for the trademark infringement and that it was primarily liable when trademarks were used as keywords to display links to the website or when these trademarks appeared on the website as refined search terms. Furthermore L'Oreal claimed that it was entitled to an injunction against eBay, even if not liable, to prohibit further infringement.

\section{(a) The Service Providers' Liability}

According to the CJEU eBay was acting as an advertiser ${ }^{72}$ when selecting keywords corresponding to a registered trademark to display sponsored links. As in the Google case ${ }^{73}$ this activity was deemed to be a use of a trademark in "the course of trade". When eBay uses keywords to promote its marketplace, the use is not related to "goods or services identical with those for which the trademark is registered" and the trademark's owner is not entitled to prohibit it. However in the case at hand the trademark was reputed and the Court pointed out that the analysis should be done in light of Article 5(2) of the TDM and of Article 9(1)(c) of the CTMR, which provide for more extensive protection. ${ }^{74}$

The situation is different when eBay uses keywords identical to a registered trademark to promote the offers of its customers. The condition of use "related to goods or services identical with those for which those trademarks are registered" is fulfilled even if the goods belong to a third party. ${ }^{75}$. The second condition, the affectation of one of the trademark's functions, could also be fulfilled. According to the Court, eBay's advertisements create an association between the trade marketed goods and the selling offer of these goods through the online marketplace. This link could have an adverse effect on trademark functions if it does not "enable reasonably well-informed and reasonably observant Internet users, or enables them only with difficulty" to ascertain the origin of the goods or services and whether there exists an economic link between the proprietor of the trademark and the undertaking, selling these goods or services ${ }^{76}$. As a

\footnotetext{
${ }^{72}$ L'Oreal (n 69) paras 84-85.

${ }^{73}$ Google (n 46) paras 51-52.

${ }^{74}$ L'Oreal (n 69) paras 89-90.

${ }^{75}$ ibid, para 91.

${ }^{76}$ ibid, para 94.
} 
final point on use, the Court stated that the operator of an online marketplace is not using the trademark when a sign identical to it appears as the content of offers for sale. The CJEU confirmed its reasoning in Google France ${ }^{77}$ stating that it is not the party that provides the service that uses the sign similar or identical to a trademark, but that the use is made by the sellers themselves, customers of the operator of the marketplace or of the service provider. $^{78}$

Turning to the hosting exemption, the findings of the Google case are confirmed: it is for the national court to determine if the service provider is an intermediary provider within the meaning of Article 14 of the Directive $2000 / 31$ and it is playing a passive role not having knowledge of nor control over the data it is processing ${ }^{79}$. It is worth noting that the Court has suggested that an active role can be inferred from the provision of assistance, especially helping customers to optimise the presentation or the promotion of the offers for sale ${ }^{80}$.

The last question answered by the court concerned the possibility for the trademark owner to demand an injunction against the service provider within the meaning of Article 11 of Directive 2004/48EC. Member States are required to ensure that national judicial authorities can:

"order the operator of an online market place to take measures which contribute not only to bringing to an end infringements of those rights by users of that marketplace, but also to preventing further infringements of that kind. Those injunctions must be effective, proportionate, dissuasive and must not create barriers to legitimate trade". 81

\section{Interflora v Marks \& Spencer}

\footnotetext{
${ }^{77}$ Google (n 46).

${ }^{78}$ L'Oreal (n 69) paras 102-103.

79 ibid, paras 107-113.

${ }^{80}$ ibid, para 114. Advocate General Jaaskinen in his Opinion considers that all eBay's activities in discussion should benefit of the hosting exemption: "It has been argued before this Court that eBay is not neutral because eBay instructs its clients in the drafting of the advertisements and monitors the contents of the listings. As I have explained, 'neutrality' does not appear to be quite the right test under the directive for this question I would find it surreal that if eBay intervenes and guides the contents of listings in its system with various technical means, it would by that fact be deprived of the protection of Article 14 regarding storage of information uploaded by the users".

${ }^{81}$ L'Oreal (n 69) para 144.
} 
Interflora is a company that operates a network of worldwide flower delivery, its trademark is registered in several Member States, it is also a Community trademark and it is well known in the majority of the Member States. Interflora brought proceedings for trademark infringement against Marks \& Spencer when it discovered that this competitor company, offering a similar service, had chosen "Interflora" as a keyword and other variants of the trademark on the AdWords service and that by consequence, its advertisement appeared among the sponsored links when "Interflora" was taped in the search engine. ${ }^{82}$

The High Court of England and Wales referred four questions to the CJEU, very similar to the questions posed in the Google and L'Oreal v eBay cases $^{83}$. The Court confirmed that the selection of a keyword by an advertiser constitutes "use in the course of trade" and made it clear that this kind of use occurs even when the advertisement triggered by the keyword does not contain the sign selected. ${ }^{84}$

\section{(a) The functions of a trademark}

Marks \& Spencer alleged that the protection of a trademark is granted only if the use of a sign identical or similar to it affects the essential function of origin and the Commission submitted the same conclusion affirming that the protection of the other trademark's functions is reserved to trademarks with reputation. The Court clearly established that it is not the sole indication of origin function that is protected but all of the "functions" of a registered trademark. Article 5(1)(a) of the TMD and Article 9(1) of the CTMR ${ }^{85}$. The Court took the opportunity offered by this case to provide interpretative guidance about a trademark's functions when a sign similar or identical to the trademark is used on the Internet, in particular on the Internet and relating to keywords, advertisement and search engines.

The CJEU examined the function of indication of origin, the advertising function and the investment function, in turn, reviewing their jurisprudence. The function of indicating origin is affected if the "reasonably well-informed and reasonably observant internet users" are not able, or it is very difficult for them, to ascertain the origin of the product or service and if

\footnotetext{
${ }^{82}$ Case C-323/09 Interflora Inc. and others v Marks and Spencer plc and others [2011] not yet published, paras 14-20.

${ }_{83}$ Google (n 46) and L'Oreal (n 69).

${ }^{84}$ Interflora (n 80) paras 30-31.

${ }^{85}$ ibid, para 38 .
} 
there is or is not an economic link between the trademark's owner and the undertaking that is advertising such product or service. Elements to be taken into account are the way the advertising is presented and the fact that in search engine cases, the trademark and the advertising containing a sign identical or similar to it, are displayed in the same page. ${ }^{86}$

The advertising function is affected when the owner of a trademark is impeded to use its mark to "inform and win over consumers" ${ }^{87}$. The use of keywords in search engines and advertising services related to them does not have that adverse effect but it proposes an alternative to the products or services that bear the trademark. ${ }^{88}$

The investment function is affected when a third party makes use of a sign identical to the trademark that has the effect of producing an interference with "the proprietor's use of its trademark to acquire or preserve a reputation capable of attracting consumers and retaining their loyalty" 89 . The same occurs for trademarks, which already have a reputation if that use can "jeopardize its maintenance" 90 .

With regard to the specific subject matter of trademarks with reputation, the Court analysed the possibilities of dilution and freeriding. The distinctive character of a trademark with reputation can be diluted if the use by a third party of a sign identical or similar to it "contributes to turning the trademark into a generic term" "91; according to the CJEU this is not always the case when a sign identical or similar to a trademark with reputation is selected from third parties as a keyword. This can occur but it is for the national judge to determine if the impact on the market of this kind of selection of keywords is strong enough to determine the perception of the trademark as a generic term. ${ }^{92}$

The most interesting point of this case is the finding arrived at by the Court in relation to the unfair advantage taken of the distinctive character. Reiterating the position taken in Google and L'Oreal v eBay, the CJEU held that the selection by third parties of a sign identical or similar to a trademark with reputation as a keyword can, if there is no due cause:

\footnotetext{
${ }^{86}$ Interflora (n 80) paras 44-50.

${ }^{87} \mathrm{ibid}$, paras $54-59$.

88 ibid.

${ }^{89}$ ibid, para 62.

${ }^{90} \mathrm{ibid}$, para 63.

${ }^{91}$ Interflora (n 80) para 79.

${ }^{92}$ ibid, para 83.
} 
“(...) be construed as a use whereby the advertiser rides on the coat-tails of a trademark with a reputation in order to benefit from its power of attraction, its reputation and its prestige, and to exploit, without paying any financial compensation and without being required to make efforts of its own in that regard, the marketing effort expended by the proprietor of that mark in order to create and maintain the image of that mark. If that is the case, the advantage thus obtained by the third party must be considered to be unfair." 93

The Court clarified that this would be more common if the advertiser offers for sale, products, which are an imitation of the goods bearing the original trademark. When the advertisement message consists in the proposal of an alternative to the products or services of the proprietor of the trademark, the use of a sign identical or similar to a trademark with reputation takes place in the ambit of fair competition. The national judge shall verify that these uses do not cause dilution or tarnishment or do not affect one of the functions of trademarks. $^{94}$

\section{The Reasoning of US Courts}

The facts in Rescuecom $v$ Google $e^{95}$ were very similar to those in Interflora $v$ Marks and Spencer. Some competitors bought keywords corresponding to the Rescuecom`s trademark on the AdWords service. The claimant alleged that internet users were deceived and diverted by this use of the trademark by a third party and sued Google, the service provider, for damages to the reputation of the trademark that is widely known in the USA. The United States Court of Appeal for the Second Circuit (hereinafter: the US Court) held that Google did not infringe Rescuecom's trademark because the use of the trademark made by the Adword service was not a use in commerce ${ }^{96}$. In

\footnotetext{
93 ibid, para 89.

${ }^{94}$ Interflora (n 80) paras 90-92.

${ }^{95}$ Case Rescuecom Corp. V Google Inc. United States Court of Appeals for the Second Circuit, 562 F.3d 123, 2009.

${ }^{96}$ Lemley, Menell, Merges, Samuelson, Carver, Software and Internet Law $\left(4^{\text {th }} \mathrm{edn}\right.$, Walters Kluwer Law \& Business 2011). The use of the trademark in commerce is essential for an action under the Latham Act, according to the Court Google's use of Rescuecom's trademark was an internal use. This decision provoked a great debate about the notion of the use in commerce even because Google alleged that his use of trademarks in the AdWord service is comparable with the product placement that retail vendors use to benefit from a competitor`s name recognition which is not prohibited by the Latham Act.
} 
it's reasoning, the Court pointed out that the circumstance that the trademark does not appear in the advertisements connected with the keyword excludes the use in commerce. This solution comes to the same result as the findings of the CJEU but in a different way, it appears that the District Court left the possibility to find a use in commerce when a trademark is exhibited in the content of the advertisement. On the contrary, the CJEU has excluded that the service provider makes a use in course of trade both when selling keywords and when triggering advertisements, which contain the trademark $^{97}$.

Regarding the liability of the advertisers, the findings of the District Court of Massachusetts are similar to the position taken by the CJEU. In the Hearts on Fire Company v Blue Nile ${ }^{98}$ case, the selection of a third party's trademark as a keyword made by an advertiser was found to be a use in commerce. The owner of the trademark has to demonstrate that this use can lead to consumer confusion. ${ }^{99}$

One of the most discussed problems is the hosting providers' liability, the jurisprudence of US District Courts is sometimes incoherent and a part of the doctrine stressed the need of clarification ${ }^{100}$. The majority of US District Courts are adopting the approach taken in Tiffany $v$ eBay ${ }^{101}$. According to this case, operators like eBay are not liable for trademark infringement only because they have a general knowledge that an infringement can occur on their site. It is the trademark owner and not the service provider that should police uses by third parties of their trademark online ${ }^{102}$. This is an interesting point that has not been considered by the CJEU.

\section{E. CONCLUding Remarks}

\footnotetext{
${ }^{97}$ Loreal (n 69).

${ }^{98}$ Case Hearts on Fire Company, LLC v Blue Nile, Inc United States District Court for the District of Massachussets, 603 F. 2d 274, 2009.

${ }^{99}$ Lemley (n 93) the notion of consumers utilised by the USA Court is 'reasonably prudent purchasers exercising ordinary care', this is not very different from the notion of enable reasonably well-informed and reasonably observant internet users adopted y the ECJ. The USA Court furthermore specifies that the confusion must occour to an appreciable number of consumers.

${ }^{100}$ T. E. Lerner, 'Playing the Blame Game, Online: Who is Liable When Counterfeit Goods are Sold Through Online Auction Houses?' (2010) 22 Pace Int LR 241.

${ }^{101}$ Case Tiffany (NJ), Inc v eBay, Inc, 576 F Supp. 2d 463.

${ }^{102}$ Lerner (n97) the duty of policing a mark online can be an element to draw the lines of service providers liability.
} 
The response in academic literature to the positions taken by the CJEU in the three cases analysed above has been widely varied. However, one common thread is the need for further clarification. ${ }^{103}$ The authors that criticised the Court's broadening of trademark protection saw these cases as the opportunity to come "back to basis"104. However, that opportunity was not taken and the protection of all trademark functions was reaffirmed. Moreover, the Court has made it clear that this protection is not reserved for trademarks with reputation ${ }^{105}$.

What appears to be particularly problematic is the application of the hosting exemption. The decisions on service providers' liability taken by national courts before these three cases lay in stark contrast. ${ }^{106}$ If on the one hand the Court has provided a clear definition of the concept of "information society service provider" and has described the requirement of "neutrality" for services to benefit of the limitation of liability, on the other hand national judges will decide if the above-mentioned condition is fulfilled ${ }^{107}$. National judges can take into account a number of elements. One example mentioned in this article is the existence of a "duty of care", if provided by national legislation. Furthermore, given the differences of the application of civil liability in the judicial systems of the Member States, the probability that the solutions will continue to diverge is high.

The CJEU appears to be struggling to find the appropriate balance between granting protection to trademarks and preserving the freedom of expression and the freedom of competition. The principles opined by the Courts in Google v Louis Vuitton, L'Oreal v eBay and Interflora v Marks \& Spencer provide a lucid and complete portrait of the conditions for the owner of a trademark or of a trademark with reputation to prevent the use in the

${ }^{103}$ Patrick Van Eecke and Maarten Truyens, 'Recent Events in EU Internet Law' (2011) 11 Journal of Internet Law 3; Christopher Morcom, 'Trade marks and the Internet: where are we now?'(2012) 34(1) European Intellectual Property Review 40; Georgios Psaroudakis, 'In search of the trade mark functions: keyword advertising in European law’ (2012) 34(1) European Intellectual Property Review 33.

${ }^{104}$ Senftleben (n 29).

${ }^{105}$ Interflora (n 80) para 38.

${ }^{106}$ T. Bednarz, C. Waelde, 'Search Engines, Keyword Advertising and Trade Marks: Fair Innovation or Free Riding?' in Law and the Internet (3th edn ed L. Edwards and C. Waelde, Hart Publishing 2009). The authors ask if keyword advertising should be regarded as fair innovation or whether that section of the marketplace should be subject to the control of the trademark owner.

${ }^{107}$ Francesco Rizzuto, 'The liability of online intermediary service providers for infringements of intellectual property rights' (2012) 18(1) Computer and Telecommunications Law Review 11. 
course of trade of a sign identical or similar to the trademark. Advertisers have the requisite elements needed to understand when the use of keywords corresponding to a trademark takes unfair advantage of the goodwill of the trademark or when it is detrimental to its reputation. ${ }^{108}$ Internet service providers can infer from the findings of the CJEU at least an idea of the extension of the exoneration from liability.

It is submitted that these main actors should be accorded the liberty to draw conclusions and reorganize their strategies in order to be able to maintain their position in a market that is in a constant state of flux.

Taking Google as an example, it is submitted that there are two potential solutions that would limit the cost of litigation and would allow search engines, such as Google, that provide an advertising service (like AdWord) to reduce the actions for trademark infringement brought against them and trademark owners (i.e. brands with a well established reputation) to monitor the use of their trademark as a keyword. One possible option for Google in order to prevent liability for trademark infringement would be to ask for the relevant documentation when advertisers select keywords that are highly risky in consideration of their reputation. This solution is currently used by Facebook. It would be very convenient for trademark owners but maybe not for Google. However, this solution would be contrary to Google's policy to be as passive a service provider as possible. Furthermore, this would reduce its profits from the AdWord service.

Another solution, less expensive for Google in terms of human resources, and quite satisfactory for the proprietors of trademarks may be suggested as follows: Google would set up a register of reputed trademarks that will make a connection between keywords identical or similar to trademarks and the owner of the respective trademark. The purpose of this connection would be to put in evidence each purchase of that kind of keyword sending a notice to the owner of the trademark. The subscription to the register would be voluntary, accompanied by documents attesting to the

\footnotetext{
${ }^{108}$ A Anderl, 'The Impact of European Supreme Court Decisions on Internet Advertising Practices', IP Client Strategies in Europe (Aspatore 2010). After Google v Vuitton and L'Oreal $v$ eBay 'every specific marketing campaign should be reviewed before its introduction to the public. The scope of such review should preliminary be the danger of the advertisement being deemed misleading for consumers. Common mistakes in practice are, for example, to deliberately use direct competitors' product names for advertisement campaigns'.
} 
identity of the trademark owner that will pay a price for each country in which they seek to subscribe.

A practical example: Louis Vuitton Italy subscribes to that register and asks to connect to its trademark the keywords 'Louis Vuitton', 'louisvuitton', 'LV'. Each time that there is a selection of these keywords in the AdWord service, a notice will be sent to the address stipulated by the owner of the trademark at the moment of subscription. This system would allow Google to continue to sell keywords without exerting control and would allow the trademark owner to monitor the use of those keywords and react promptly if there is an infringing use in the course of trade. ${ }^{109}$

${ }^{109}$ These proposals have been conceptualised in collaboration with the consulting service of Riccardo Visione, computer engineering student, riccardovisione@gmail.com. 